\title{
Effect of hard metal dust on ventilatory function
}

\author{
Y KUSAKA, Y ICHIKAWA, T SHIRAKAWA, AND S GOTO \\ From the Department of Hygiene, Medical School, Osaka University, Osaka City, 530 Japan
}

ABSTRACT The effect of hard metal dust generated in shaping on ventilatory function has been studied, in particular, the relation between levels of exposure to cobalt and changes in ventilatory function. In 15 healthy young men a significant decrease in FVC occurred after a six hour exposure to hard metal dust containing cobalt at a mean concentration of $38 \mu \mathrm{g} / \mathrm{m}^{3}$ (range $14-76 \mu \mathrm{g} / \mathrm{m}^{3}$ ). No dose-effect relation could be discerned between the decrease in FVC and the hard metal concentration or the cobalt concentration. All the subjects complained of irritation of the airways. On the other hand, in 42 shaping workers exposed to cobalt at an average concentration of $85 \mu \mathrm{g} / \mathrm{m}^{3}$ no significant decreases in ventilatory function were detected after seven hour exposures to hard metal, although in 42 shapers, who had been exposed to cobalt at a mean concentration of $126 \mu \mathrm{g} / \mathrm{m}^{3}$, the $\mathrm{FEV}_{1} \%$ was significantly decreased compared with matched controls. This finding suggests that hard metal dust containing cobalt at a mean concentration of $126 \mu \mathrm{g} / \mathrm{m}^{3}$ causes chronic bronchial obstruction.

Occupational asthma is known to occur among hard metal workers ${ }^{1-5}$ and some studies have shown that cobalt is the causative agent. ${ }^{25}$ Roto reported that workers in the Finnish refinery industry developed asthma when exposed to cobalt at a concentration of less than $0.1 \mathrm{mg} / \mathrm{m}^{3} .^{6}$ Kusaka et al reported that asthma may be caused by cobalt at a mean time weighted average concentration below $0.05 \mathrm{mg} / \mathrm{m}^{3}$. To prevent interstitial pneumonitis occurring among hard metal workers, the American Conference of Governmental Industrial Hygienists has indicated their intention to change the eight hour TWA TLV for cobalt from $0.1 \mathrm{mg} / \mathrm{m}^{3}$ to $0.05 \mathrm{mg} / \mathrm{m}^{38}$ on the basis of the animal experiments carried out by Kerfoot et al. ${ }^{9}$ Alexandersson et al have reported that obstructive ventilatory changes have progressed among powder workers and shapers in the hard metal industry exposed to an average cobalt concentration of $0.06 \mathrm{mg} / \mathrm{m}^{3}$. $^{10-13}$

We have studied the effect of hard metal dust containing cobalt on the ventilatory function of both health controls and hard metal shaping workers. In particular, the relation between cobalt concentrations and ventilatory changes has been examined.

\section{Subjects and methods}

An occupational hygienic survey consisting of both medical and environmental studies was conducted in a hard metal factory from 1981 to $1984 .{ }^{7}$ During this Accepted 20 July 1985 period, both cobalt concentrations and total hard metal dust concentrations for all shapers were measured at least twice on different days by the method described previously. ${ }^{7}$

The manufacturing process of hard metal has been fully documented by Kusaka et al. ${ }^{7}$ Tungsten carbide and cobalt are mixed, pressed into desired shapes, and presintered. In some cases a small amount of tantalum carbide, titanium carbide, nickel, and so on are added. Tungsten carbide constitutes $80-90 \%$ of hard metal by weight and cobalt $5-10 \%$ as matrix. Presintered hard metal, which is as hard as chalk, is then shaped. Workers engaged in shaping are called shapers. Of the total dust in the shaping room, $75 \%$ was respirable.

In October 198415 healthy young men were seated at rest in the shaping room for six hours (1300-1900) and inhaled hard metal dust generated by the shaping process. Indices of ventilatory function-FVC, $\mathrm{FEV}_{1}, \mathrm{FEV}_{1 \%}$, peakflow, maximum midexpiratory flow, $\mathrm{V} \max _{50 \%} \mathrm{vc}$, and $\dot{\mathrm{V}} \max _{25} \% \mathrm{vc}$-were measured just before and immediately after the exposure. Hard metal exposure and cobalt exposure concentrations were determined during the full exposure period by the method described previously. ${ }^{7}$ Additionally, the same 15 men sat at rest from 1300 to 1900 without smoking and with no exposure to dust. Ventilatory function was measured at 1300 and 1900 . The mean age of the 15 men was 24 (SD 2 years) and their mean height was $171 \mathrm{~cm}$ (SD $4 \mathrm{~cm})$. Eight of the $15(53 \%)$ were smokers. 
From September to November 1984, ventilatory function was measured in $\mathbf{4 2}$ shapers just before and immediately after a seven hour exposure to hard metal dust (0830-1630). Their eight hours work began at 0830 and ended at 1730; lunch was taken from 1200 to 1300 . Hard metal and cobalt exposure levels were monitored for the seven hour working day by the method previously described.

The mean and standard deviation of the duration of exposure to hard metal for the $\mathbf{4 2}$ shapers was 10 years and four years, respectively, range 2-20 years. Three had worked as powder workers and one as a wet grinder before being transferred to the shaping department. The remaining 38 shapers had been exposed to hard metal all the time. The medical examination showed that three of the 42 employees had occupational asthma related to hard metal. ${ }^{7}$ In two of the three the asthmatic attacks occurred while this study was being conducted and one man had to be administered bronchodilators which were stopped on the day before his ventilatory function was measured. No cases of interstitial pneumonitis were found. None of the shapers wore respirators on the day the respiratory function was measured.

During the working days in July 1984 , ventilatory function was measured in the 42 shapers and in a control group of 84 unexposed workers matched for sex, age, height, and smoking habits (table 1).

Ventilatory function was measured with a rolling seal type spirometer (Spirotest-85, Chest) and flow was obtained from differentiating volume. The accuracy was within $2 \%$ both for the volume and for the flow. The volume range was up to 101 , the flow range was between 0 and $151 / \mathrm{s}$, and the internal resistance

Table 1 Characteristics of shapers and controls

\begin{tabular}{lcc}
\hline & Shapers & Controls \\
\hline No: & 42 & 84 \\
Men & 34 & 68 \\
Women & 8 & 16 \\
Age (years) & $42 \pm 9$ & $42 \pm 9$ \\
Height (cm) & $162 \pm 8$ & $163 \pm 7$ \\
Smoking habit: & 21 & 42 \\
Smoker & 6 & 12 \\
Ex-smoker & 15 & 30 \\
Non-smoker & & \\
\hline
\end{tabular}

was $0.2 \mathrm{~cm} \mathrm{H}_{2} \mathrm{O}$ for any flow. The frequency response ranged from 0 to over $10 \mathrm{~Hz}$. The spirometer had a CRT display of 9 inches and flow volume curves were displayed on it at real time.

At least three forced expiratory manoeuvres were performed; the best flow volume curve with the largest sum of FVC and FEV 1 was selected for analysis. ${ }^{14}$ All results were expressed in BTPS.

Changes in ventilatory function over time were calculated by subtracting the value obtained at the earlier point from the later one, yielding a negative value for a decrease and a positive for an increase. Differences between ventilatory changes after exposure to hard metal and diurnal changes in the 15 youths were examined using a paired $t$ test. The significance of differences between preshift and postshift respiratory function in the $\mathbf{4 2}$ shapers was also evaluated using paired $t$ tests. The correlation between ventilatory changes and hard metal dust concentrations or cobalt concentrations was also analysed by paired $t$ tests. Differences in the mean values in ventilatory function between the shapers and the controls were examined with an unpaired $t$ test. Differences with $p<0.05$ were regarded as statistically significant.

\section{Results}

VENTILATORY CHANGES IN 15 YOUNG MEN AFTER SIX HOUR EXPOSURE

The mean hard metal dust concentration for the 15 young men was $0.8 \mathrm{mg} / \mathrm{m}^{3}$ with SD $0.4 \mathrm{mg} / \mathrm{m}^{3}$ (range $0.4-1.6 \mathrm{mg} / \mathrm{m}^{3}$ ). The mean cobalt concentration was $38 \mu \mathrm{g} / \mathrm{m}^{3}$ with SD $22 \mu \mathrm{g} / \mathrm{m}^{3}$ (range $14-76 \mu \mathrm{g} / \mathrm{m}^{3}$ ). Table 2 shows ventilatory changes after exposure to hard metal for six hours and diurnal variations in ventilatory function. The FVC decreased significantly after exposure to hard metal compared with the physiological diurnal change. There were no significant correlations between the decrease in FVC and the hard metal concentration or the cobalt concentration.

VENTILATORY CHANGES IN 42 SHAPERS AFTER SEVEN HOUR EXPOSURE

The mean hard metal dust concentration was $1.4 \mathrm{mg} / \mathrm{m}^{3}$ with SD $0.8 \mathrm{mg} / \mathrm{m}^{3}$ (range $0 \cdot 2-2.4 \mathrm{mg} / \mathrm{m}^{3}$ )

Table 2 Ventilatory changes after exposure to hard metal and diurnal changes in 15 healthy young men

\begin{tabular}{|c|c|c|c|c|c|c|c|c|}
\hline & & $\begin{array}{l}\Delta F V C \\
(l)\end{array}$ & $\begin{array}{l}\triangle F E V_{1} \\
(l)\end{array}$ & $\underset{(\%)}{\triangle F E V_{1} \%}$ & $\begin{array}{l}\Delta P F \\
(l / s)\end{array}$ & $\begin{array}{l}\Delta M M F \\
(l / s)\end{array}$ & $\underset{(l / s)}{\Delta V_{s 0}}$ & $\Delta V_{(l / s)}$ \\
\hline $\begin{array}{l}\text { Changes after exposure } \\
\text { Diurnal changes }\end{array}$ & $\begin{array}{l}\text { Mean } \\
\text { SD } \\
\text { Mean } \\
\text { SD }\end{array}$ & $\begin{array}{l}-0 \cdot 10^{*} \\
(0 \cdot 10) \\
+0 \cdot 05 \\
(0 \cdot 20)\end{array}$ & $\begin{array}{l}-0.06 \\
(0.08) \\
+0.04 \\
(0.17)\end{array}$ & $\begin{array}{l}+0.64 \\
(1 \cdot 24) \\
-0.59 \\
(2 \cdot 52)\end{array}$ & $\begin{array}{l}-0.08 \\
(0.52) \\
+0.11 \\
(0.80)\end{array}$ & $\begin{array}{l}+0.07 \\
(0 \cdot 21) \\
-0 \cdot 10 \\
(0.40)\end{array}$ & $\begin{array}{l}-0.07 \\
(0.44) \\
+0.02 \\
(0.57)\end{array}$ & $\begin{array}{l}+0.07 \\
(0.19) \\
-0.35 \\
(0.85)\end{array}$ \\
\hline
\end{tabular}

*p $<0.05$. 
Table 3 Changes in ventilatory function after exposure to hard metal among 42 shapers

\begin{tabular}{|c|c|c|c|c|c|c|c|}
\hline & $\begin{array}{l}\Delta F V C \\
\text { (l) }\end{array}$ & $\begin{array}{l}\triangle F E V_{1} \\
(l)\end{array}$ & $\underset{(\%)}{\Delta F_{1 \%}}$ & $\begin{array}{l}\Delta P F \\
(l / s)\end{array}$ & $\begin{array}{l}\Delta M M F \\
(l / s)\end{array}$ & $\underset{(l / s)}{\Delta V_{s o}}$ & $\begin{array}{l}\Delta \dot{V}_{25} \\
(l / s)\end{array}$ \\
\hline $\begin{array}{l}\text { Mean } \\
\text { SD }\end{array}$ & $\begin{array}{r}+0.01 \\
0.19\end{array}$ & $\begin{array}{r}+0.01 \\
0.19\end{array}$ & $\begin{array}{r}-0.28 \\
3.66\end{array}$ & $\begin{array}{r}+0.15 \\
1.10\end{array}$ & $\begin{array}{r}-0.01 \\
0.48\end{array}$ & $\begin{array}{r}-0.01 \\
0.47\end{array}$ & $\begin{array}{r}-0.10 \\
0.35\end{array}$ \\
\hline
\end{tabular}

in 42 shapers. The mean cobalt concentration was $85 \mu \mathrm{g} / \mathrm{m}^{3}$ with SD $92 \mu \mathrm{g} / \mathrm{m}^{3}$ (range $17-610 \mu \mathrm{g} / \mathrm{m}^{3}$ ). There were no significant changes in any ventilatory indices in the shapers (table 3).

\section{VENTILATORY FUNCTION IN SHAPERS AND}

\section{CONTROLS}

From 1981 to 1984 , the shapers were exposed to hard metal dust at a concentration of $1.6 \mathrm{mg} / \mathrm{m}^{3}$ on average (number of air samples 129, SD $1.9 \mathrm{mg} / \mathrm{m}^{3}$, range $\left.0.1-14.6 \mathrm{mg} / \mathrm{m}^{3}\right)$, and to cobalt at a mean concentration of $126 \mu \mathrm{g} / \mathrm{m}^{3}\left(\mathrm{n}=129\right.$, SD $191 \mu \mathrm{g} / \mathrm{m}^{3}$, range 6-610 $\left.\mu \mathrm{g} / \mathrm{m}^{3}\right){ }^{6}$

All ventilatory indices were lower in the shapers than the controls, significantly so in the case of the FEV $_{1 \%}$ (see table 4).

Table 4 Ventilatory function in shapers and controls

\begin{tabular}{|c|c|c|}
\hline & Shapers & Controls \\
\hline & $M e a n \pm S D$ & $M e a n \pm S D$ \\
\hline 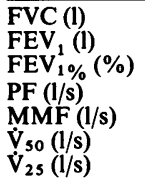 & $\begin{array}{c}3.67 \pm 0.82 \\
3.12 \pm 0.81 \\
84.79 \pm 8.16^{*} \\
8.81 \pm 2.25 \\
3.47 \pm 1.28 \\
3.76 \pm 1.34 \\
1.38 \pm 0.77\end{array}$ & $\begin{array}{r}3.78 \pm 0.69 \\
3.30 \pm 0.65 \\
87.14 \pm 5.47 \\
9.04 \pm 2.14 \\
3.83 \pm 1.27 \\
4.12 \pm 1.37 \\
1.51 \pm 0.86\end{array}$ \\
\hline
\end{tabular}

${ }^{*} \mathrm{p}<0.05$.

\section{Discussion}

Alexandersson et al pointed out that 73 hard metal powder and shaping workers exposed to cobalt at a mean concentration of $60 \mu \mathrm{g} / \mathrm{m}^{3}$ (range $10-150$ $\mu \mathrm{g} / \mathrm{m}^{3}$ ) for eight years on average developed significant decreases in FVC, FEV , $^{\text {, and } M M F}$ after a day at work. ${ }^{10-13}$ There was a positive correlation between the decrease in FEV 1 and the cobalt concentration in the urine. The workers were reported to have significant decreases in $\mathrm{FEV}_{1}, \mathrm{FEV}_{1 \%}$, and MMF compared with those of the controls. FEV 1 had a tendency to decrease as the duration of exposure to hard metal increased. The decrease in $\mathrm{FEV}_{1}$ was larger in smoking workers than in nonsmokers. On the other hand, no ventilatory changes were found in hard metal grinding workers who were exposed to cobalt at a mean level of $12 \mu \mathrm{g} / \mathrm{m}^{3}$ (range $\left.3-34 \mu \mathrm{g} / \mathrm{m}^{3}\right)$. Alexandersson et al related the decreases in ventilatory function to cobalt exposure but did not mention the mechanism for the decrease. ${ }^{10-13}$

The positive dose effect relation between cobalt concentrations in the urine and a decrease in FEV 1 observed by Alexandersson et al suggests that the ventilatory decrease may be caused by cobalt. But, since hard metal always contains a certain amount of cobalt, a dose effect relation between hard metal dust concentrations themselves and ventilatory changes would also be expected. Hard metal contains other elements besides colbalt and hard metal grinding workers are also exposed to cutting fluids and dust generated from grinding wheels. ${ }^{7}$ Thus pulmonary changes occurring in such workers should not necessarily be regarded as being caused by cobalt.

In our study of 15 healthy young men a significant decrease in FVC occurred after exposure to hard metal for six hours at a mean cobalt concentration of $38 \mu \mathrm{g} / \mathrm{m}^{3}$. All complained of coughing, expectoration, or a sore throat during and after the exposure but neither rales nor wheezing was observed. None had been exposed to hard metal before the experiment. Thus the mechanism of the ventilatory change is probably the result of an irritant effect on the large bronchi.

Irritant symptoms, similar to those seen in the 15 young men, were also observed among the hard metal workers between 1981 and 1984. We found that several workers developed not asthma but irritation of the airways between a couple of days and a few weeks after they were first employed in the factory or were transferred to more dusty work. They recovered fully when they wore respirators or were transferred to non-dusty work. In some cases respiratory symptoms disappeared spontaneously. Fairhall et al also point out that hard metal dust had irritative effects on the upper airways and the mucous membranes. ${ }^{15}$

The 15 healthy men studied by us were exposed to cobalt at a mean concentration of $38 \mu \mathrm{g} / \mathrm{m}^{3} ; 73$ hard metal workers studied by Alexandersson et al were exposed to cobalt at $60 \mu \mathrm{g} / \mathrm{m}^{3}$ (mean) ${ }^{10-13}$ and the 42 shapers studied by us were exposed to cobalt at a concentration as high as $85 \mu \mathrm{g} / \mathrm{m}^{3}$ (mean). The hard metal dust to which both the 42 shapers and the 15 healthy men were exposed probably has the same properties as that to which the $\mathbf{7 3}$ hard metal workers studied by Alexandersson were exposed. The differences in exposure time of these three groups may be disregarded. Nevertheless, significant decreases in 
FVC, $\mathrm{FEV}_{1}, \mathrm{PF}$, or MMF as seen in the 15 youths or in the 73 hard metal workers were not detected in the 42 shapers.

We presume there must be some reasons to account for this fact. Firstly, the characteristics of the workers studied by us differ from those of the hard metal employees examined by Alexandersson et al. ${ }^{10}$ At least 24 of the workers they studied complained of tightness in the chest. As an intensive medical examination was not carried out in their study, however, we cannot tell if any had asthma related to hard metal dust although this seems likely. In our study only two workers complained of wheezing and both had occupational asthma when their ventilatory capacity was measured. Secondly, a so called survival effect may have affected the results of our study. For example, some workers who had already developed asthma due to exposure to hard metal had left the factory. ${ }^{7}$ Thirdly, workers may become tolerant to hard metal dust as the result of daily, continuous exposure. Consequently, ventilatory decreases may not occur. ${ }^{7}$

The shapers had a significant decrease in $\mathrm{FEV}_{1 \%}$ compared with the controls: Alexandersson et al showed significant decreases in both $\mathrm{FEV}_{1}$ and MMF among hard metal workers with a cobalt exposure of $0.06 \mathrm{mg} / \mathrm{m}^{3} \cdot{ }^{10-13}$ Our result suggests that exposure to hard metal dust at a mean level of $1.6 \mathrm{mg} / \mathrm{m}^{3}$ and cobalt in air at a concentration of $126 \mu \mathrm{g} / \mathrm{m}^{3}$ on average causes chronic obstruction of the bronchi.

\section{References}

${ }^{1}$ Bruckner HC. Extrinsic asthma in a tungsten carbide worker. $J$ Occup Med 1967;9:518-9.

${ }^{2}$ Coates EO, Sawyer HJ, Rebuck JW, Kvale PA, Sweet LW. Hypersensitivity bronchitis in tungsten carbide workers. Chest 1973;64:390.
${ }^{3}$ Sjögren I, Hillerdal G, Andersson A, Zetterström O. Hard metal lung disease; importance of cobalt in coolants. Thorax 1980;35:653-9.

${ }^{4}$ Hartmann A, Wüthrich B, Bolognini G. Berufsbedingte Lungenkrankheiten bei der Hartmetallproduktion undbearbeitung. Ein allergisches Geschehen? Schweiz Med Wochenschr 1982;112:1137-41.

${ }^{5}$ Davison AG, Haslam PL, Corrin B, Studdy PR, Newman-Taylor AJ. Interstitial lung disease and asthma in hard-metal workers: bronchoalveolar lavage, ultrastructural and analytical findings and results of bronchial provocation tests. Thorax 1983; 38:119-28.

${ }^{6}$ Roto P. Asthma, symptoms of bronchitis and ventilatory capacity among cobalt and zinc production workers. Scand J Work Environ Health 1980;6 suppl 1:1-49.

${ }^{7}$ Kusaka Y, Yokoyama K, Sera Y, et al. Respiratory diseases in hard metal workers: an occupational hygienic study in a factory. Br J Ind Med 1986;43:474-85.

${ }^{8}$ American Conference of Governmental Industrial Hygienists. Threshold limit values for chemical substances and physical agents in the workroom environment with intended changes for 1981. Cincinnati: ACGIH, 1981.

${ }^{9}$ Kerfoot EJ, Fredrick WG, Domeier E. Cobalt metal inhalation studies on miniature swine. Am Ind Hyg Assoc J 1975;36:17-25.

${ }^{10}$ Alexandersson R, Swensson A. Studies on the pulmonary reaction of workers exposed to cobalt in the tungsten carbide industry. Arh Hig Rada Toksikol 1979;30 suppl:17-25.

${ }^{11}$ Alexandersson R, Bergman K. Effects of exposure to cobalt. 2. Respiratory system reactions to different exposures in the cemented-carbide industry. Arbete och Halsa 1979;2:1-34.

12 Alexandersson R, Hedenstierna G, Lidums V. Effects of exposure to cobalt. 3. Ventilatory capacity, distribution of inhaled gas and ventilatory obstruction during and after exposure. Arbete och Halsa 1979;7:1-25.

${ }^{13}$ Gustavsson P, Lidums V, Swensson A, Alexandersson R. Effects of exposure to cobalt. 6. Exposure, absorption and pulmonary effects in the cemented-carbide industry. Arbete och Halsa 1979;10:1-24.

${ }^{14}$ Gardner RM, chairman. Snowbird workshop on standardization of spirometry. ATS statement. Am Rev Respir Dis 1979;119:831-8.

${ }^{15}$ Fairhall LT, Castberg HT, Carrozzo NJ, Brinton HP. Industrial hygiene aspects of the cemented tungsten carbide industry. Occupational Medicine 1947;4:371-9. 